Akuntansi dan Manajemen

Vol.14, No.1, 2019, Hal. 104-110

\title{
SOSIALISASI AKUNTANSI PERPAJAKAN BAGI SISWA SMK JURUSAN AKUNTANSI
}

\author{
Fera Sriyunianti \\ Politeknik Negeri Padang \\ Email: ferasriyunianti@gmail.com
}

\begin{abstract}
Abstrak
Akuntansi pajak merupakan satu kompetensi yang penting dimiliki oleh siswa SMK Jurusan Akuntansi. Tujuan akuntansi pajak adalah menetapkan besaran pajak terhutang dan mencatatnya dalam pelaporan keuangan. Berdasarkan data yang ada masih banyak guru dan siswa akuntansi di Sekolah Tingkat Menengah yang belum memahami akuntansi pajak sehingga kompetensi lulusan yang diinginkan tidak terwujud. Penyebabnya antara lain kurang memiliki iteratur, kurangnya pemahaman akan akuntansi pajak itu sendiri serta soal-soal akuntansi pajak kurang bervariasi. Tujuan pengabdian ini adalah memberikan pemahaman dan keterampilan para guru dan siswa SMK jurusan akuntansi tentang akuntansi pajak mulai dari menghitung hingga melaporkan pajak itu sendiri. Khalayak sasarannya adalah guru dan siswa akuntansi di SMKN 2 Padang. Kegiatan yang dilakukan adalah memberikan pelatihan akuntansi pajak, pembuatan modul akuntansi pajak yang disederhanakan serta pembuatan soal yang bervariasi. Hasil yang diharapkan dari pengabdian ini adalah target memahami dan trampil dalam akuntansi pajak serta memiliki buku referensi mengenai akuntansi pajak.
\end{abstract}

Keyword; Akuntansi, Pajak, SMK, UU Perpajakan

\begin{abstract}
Tax accounting is a part of important competence for an accounting student.The purpose of tax accounting is to set the outstanding tax according to the financial reports. There are many accounting teachers and students of accounting in secondary schools who do not understand tax accounting. The cause of all that is the lack of tax accunting literatures, the lack of understanding of tax accounting itself and practice tax case that are less varied. The purpose of this service is to provide a tax accounting for accounting teachers and students ranging from counting to reporting tax itself. The workshop targets are accounting teachers and students of SMKN 2 Padang. Workshop activities are providing training in tax accounting, making a simplified tax accounting module and making various tax accounting cases. The expectation results from this service are the existence of targets who understand and are skilled in tax accounting.
\end{abstract}

Keyword; Accounting, Tax, SMK, Tax Act 


\section{Pendahuluan}

Pajak merupakan salah satu sumber penghasilan 'primadona' negara saat ini. Hampir disetiap sektor kehidupan tidak terlepas dengan adanya pajak. Hal ini cukup dimaklumi sebagai akibat telah menurunnya penghasilan negara dari sektor migas yang cukup drastis sedangkan kebutuhan kehidupan bernegara membutuhkan biaya yang sangat besar. Biaya kesehatan, biaya pendidikan, biaya infrastruktur, belanja pegawai negeri dan sebagainya tidak akan tertutupi apabila negara hanya mengandalkan sumber pendapatan dari non pajak. Semakin banyak pajak yang diperoleh, maka diharapkan semakin banyak fasilitas dan infrastruktur yang dibangun.

Indonesia saat ini telah menganut sistem perpajakan self assesment dimana setiap wajib pajak diberikan kewenangan untuk menghitung, melaporkan dan membayar sendiri pajak terhutangnya. Oleh karena itu, penting bagi setiap wajib pajak untuk mengetahui jenis, tata cara dan penghitungan pajak yang berlaku di Indonesia. Apalagi jika dikaitkan dengan dunia usaha dan pemerintahan yang memiliki keterlibatan yang sangat besar selaku wajib pajak maupun pengelola pajak. Mereka sangat membutuhkan orang-orang yang memahami dan menguasai perpajakan. Oleh karena itu, wajar saja apabila mereka yang menguasai dan memahami perpajakan akan mudah diterima bekerja di lembaga pemerintahan maupun swasta.

Sekolah Menengah Kejuruan (SMK) merupakan salah satu pendidikan vokasi yang tujuannya mencetak peserta didik yang siap pakai di dunia kerja. SMK merupakan pendidikan vokasi yang berada di bawah binaan Direktorat Pendidikan Menengah dan Kejuruan (Dikmenjur). Secara umum SMK terbagi atas 2 jenis, yaitu bidang Teknologi dan bidang Bisnis dan Manajemen. Salah satu jurusan yang paling banyak peminatnya di SMK Bisnis dan Manajemen adalah jurusan Akuntansi. Kompetensi utama yang diharapkan dari siswa yang lulus dari jurusan akuntansi ini adalah mampu membuat laporan keuangan serta memahami perpajakan. Walaupun demikian, akuntansi dan perpajakan bukanlah 2 bidang ilmu terpisah, melainkan saling berkaitan. Hal ini akan sangat terasa ketika lulusan SMK yang terlibat dalam dunia usaha, harus memiliki pemahaman di bidang perpajakan dan bagaimana mencatatnya dalam pembukuan perusahaan. Elaborasi kedua bidang ini dikenal dengan istilah Akuntansi Pajak dan biasanya dipelajari di tingkat perguruan tinggi.

Akuntansi pajak merupakan bagian dari kompetensi penting untuk dimiliki oleh siswa SMK Jurusan Akuntansi. Akuntansi Pajak tercipta karena adannya suatu prinsip dasar yang diatur dalam UU Perpajakan dan pembentukannya terpengaruh oleh fungsi perpajakan dalam mengimplementasikannya sebagai kebijakan pemerintah. Tujuan akuntansi pajak adalah menetapkan besarnya pajak terhutang berdasarkan laporan keuangan yang telah disusun. Namun sayangnya, materi untuk akuntansi pajak yang diajarkan saat ini di SMK kurang up to date dengan peraturan perpajakan yang ada di Indonesia. Peraturan perpajakan di Indonesia hampir tiap 
periode mengalami perubahan, namun yang diajarkan seringkali masih yang lama. Hal ini terbukti ketika mengikuti Olimpiade Akuntansi tingkat SMK Se- Sumatra yang diadakan Politeknik Negeri Padang tahun 2015 dan 2016, siswa yang dapat menjawab soal perpajakan dengan benar cuma dua orang dan mereka itupun berasal dari SMK yang sama. Setelah dikonfirmasi ke guru-guru pembimbingnya, ternyata memang para siswa dan guru belum mengetahui perubahan-perubahan dalam undang-undang perpajakan dan bagaimana perlakuan akuntansi untuk perpajakan tersebut. Bukti lainnya bahwa akuntansi perpajakan masih terasa sulit adalah pada saat Lomba Kompetensi Siswa (LKS) yang diadakan bulan Maret 2017 tingkat Kota Padang yang diselenggarakan oleh Politeknik Negeri Padang, menunjukkan bahwa siswa tidak mampu menjawab kasus tentang perpajakan. Kondisi tersebut sangat disayangkan sekali mengingat kompetensi dibidang perpajakan untuk siswa akuntansi di SMK merupakan kompetensi yang harus dimiliki agar mereka cepat diserap oleh lapangan pekerjaan, hal ini dikarenakan dimanapun nantinya mereka bekerja baik di sektor swasta maupun pemerintah, baik itu perusahaan besar maupun kecil, semuanya membutuhkan orang-orang yang paham akan perpajakan.

Berdasarkan paparan fenomena di atas, maka perlu dilakukan suatu sosialiasi mengenai pentingnya pengetahuan dan pemahaman akuntansi pajak yang dimiliki oleh seorang lulusan SMK. Untuk mencapai tujuan tersebut, maka dipilih SMKN 2 Padang sebagai mitra kegiatan sosialisasi. Selain lokasinya berada di kota besar, sekolah ini juga telah terakreditasi A, sehingga diharapkan dapat menjadi contoh sebagai satu sekolah kejuruan yang telah mengenal akuntansi perpajakan.

\section{Permasalahan Mitra}

Sebagaimana yang telah dipaparkan sebelumnya, salah satu kompetensi standar yang harus dimiliki seorang lulusan SMK Jurusan Akuntansi adalah dibidang perpajakan. Kompetensi ini membahas tentang peraturan perpajakan bagaimana menghitung pajak, mencatat, melaporkan dan membayar pajak. Hal ini menjadikan setiap siswa SMK wajib untuk memahami dan lulus di bidang perpajakan dasar. Walaupun demikian, perpajakan tidak bisa terlepas dengan akuntansi, begitu juga sebaliknya sehingga perlu adanya pemahaman mengenai kedua bidang tersebut yang dikenal dengan nama Akuntansi Pajak.

Berdasarkan hasil perlombaan LKS akuntansi siswa tingkat Kota Padang Maret 2017 yang lalu terbukti bahwa para siswa umumnya tidak mampu mengerjakan kasus akuntansi perpajakan. Selain itu, berdasarkan wawancara dengan mitra diketahui bahwa mereka juga belum mengajarkan akuntansi perpajakan yang komprehensif. Keterbatasan kurikulum dan sumber daya menjadi beberapa faktor penyebabnya. Padahal, pengetahuan dasar akuntansi perpajakan juga perlu dimiliki seorang lulusan SMK Jurusan Akuntansi yang memiliki jargon siap terjun ke dunia usaha.

Ada beberapa hal yang diduga bisa menjadi penyebab minimnya pengetahuan akuntansi pajak, antara lain: 
1. Kurangnya pemahaman tentang Akuntansi Perpajakan

Selama ini para guru dan siswa sekolah kejuruan memahami bahwa akuntansi dan perpajakan adalah dua bidang yang berbeda dan terpisah satu dengan lainnya. Pemahaman tersebut tidaklah dapat disalahkan karena literatur yang ada selama ini, khususnya level sekolah menengah kejuruan, memang banyak membahas akuntansi dan perpajakan secara terpisah. Umumnya literatur akuntansi perpajakan diperuntukan untuk perguruan tinggi. Selain itu menurut mitra, kesempatan untuk mengikuti pelatihan maupun bimbingan teknis tentang perkembangan akuntansi, khususnya dalam akuntansi pajak, sangat sulit didapat oleh para guru. Kesulitan yang dialami guru berimbas pada pengetahuan dan kemampuan siswanya dalam menghitung dan mencatat pajak. Padahal akuntansi pajak merupakan suatu kompetensi yang wajib dimiliki siswa jurusan akuntansi.

2. Persoalan kurangnya literatur mengenai Akuntansi Perpajakan

Beberapa tahun ini undang-undang perpajakan ini sering mengalami perubahan hampir setiap tahunnya. Sebagai akibat kurangnya pelatihan perpajakan dan akuntansi perpajakan bagi guru-guru sekolah kejuruan menyebabkan mereka kurang mengetahui perkembangan perpajakan terbaru, khususnya terhadap perkembangan undang-undang perpajakan. Selain itu, kurangnya ketersediaan referensi atau modul ajar tentang akuntansi perpajakan untuk siswa SMK jurusan Akuntansi juga diduga mendukung minimnya pengetahuan dan pemahaman mereka.

3. Kurangnya contoh soal dan kasus yang bervariasi

Kedua persoalan di atas pada akhirnya berimbas juga dalam kegiatan belajarnya. Pemberian kasus-kasus akuntansi yang komprehensif, mulai dari pencatatan transaksi sampai pada penghitungan pajaknya serta pencatatannya kembali, diakui sangat minim. Selain itu, rendahnya variasi soal-soal latihan baik dibidang akuntansi maupun perpajakan setiap tahunnya juga dinilai cukup mempengaruhi pengetahuan siswa. Padahal dengan soal kasus yang bervariasi diharapkan pemahaman dan kemampuan guru dan siswa dibidang akuntansi, khusunya akuntansi pajak, dapat ditingkatkan.

\section{Solusi yang ditawarkan}

Berdasarkan hasil penelusuran di atas, maka ditawarkan beberapa solusi berikut yang diharapkan dapat mengatasi masalah yang dihadapi guru dan siswa dibidang akuntansi perpajakan, yaitu:

1. Perancangan dan pembuatan modul ajar

Perancangan modul ajar merupakan sekumpulan materi perpajakan khususnya mengenai pajak penghasilan yaitu PPh pasal 21 dan PPh pasal 22. Selain membahas perhitungannya juga dibahas akuntansi perpajakannya (pencatatannya).

Pembuatan modul atau bahan ajar akuntansi pajak ini dibuat dengan bahasa 
yang disederhanakan dengan materi peraturan perundangan perpajakan terbaru. Diharapkan dengan adanya bahan ajar ini akuntansi perpajakan mudah dipahami dan ter up to date. Selain materi mengenai akuntansi perpajakan juga dibuatkan soal pajak yang komprehensif untuk siswa SMK jurusan akuntansi. Dengan adanya soal yang bisa dijadikan untuk latihan siswa diharapkan pemahaman dan kemampuan siswa dalam menyelesaikan akuntansi pajak.

2. Pelatihan akuntansi perpajakan.

Pelatihan diberikan untuk guru dan siswa mulai dari mencatat transaksi, menghitung pajak, membayar dan melaporkan pajak. Sehingga setelah pelatihan ini diharapkan pemahaman dan pengetahuan guru dan siswa dalam akuntansi perpajakan bertambah.

Berikut suasana pelatihan akuntansi perpajakan di SMKN 2 Padang:

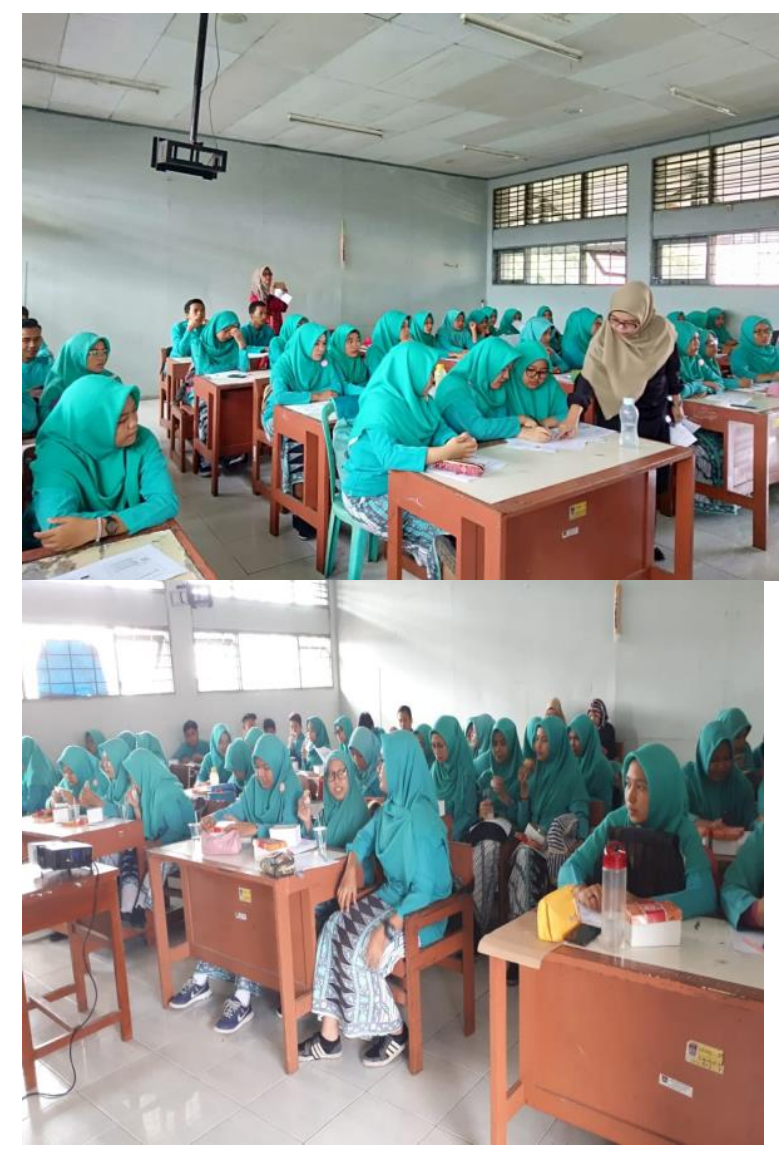

3. Pemberian peralatan, berupa :
a. Buku Perpajakan
b. Buku Akuntansi Pajak

Buku-buku tersebut diserahkan untuk menambah referensi mengenai 
perpajakan dan akuntansi perpajakan. Berikut suasana penyerahan buku-buku perpajakan dan akuntansi perpajakan:

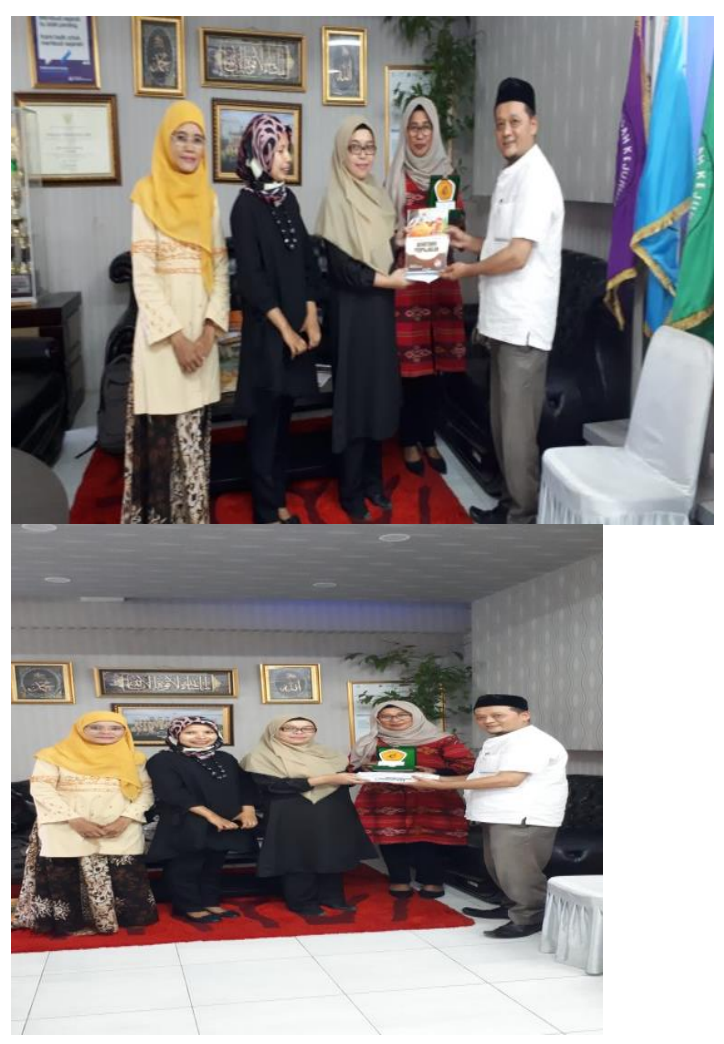

\section{Kesimpulan}

1. SMKN 2 Padang merupakan salah satu sekolah menengah kejuruan terakreditasi namun sebagian siswanya belum memenuhi kompetensi perpajakan dan akuntansi perpajakan

2. Kondisi tersebut dibuktikan dari masih rendahnya kemampuan para siswanya menjawab soal-soal kasus berbagai macam perlombaan akuntansi dan perpajakan yang diikuti.

3. Beberapa penyebab kekurangan tersebut antara lain kurangnya pelatihan dan sosialisasi akuntansi perpajakan, kurangnya literatur mengenai akuntansi perpajakan dan kurang bervariasinya soal-soal kasus akuntansi perpajakan.

4. Permasalahan tersebut diatasi dengan cara memberikan sosialisasi dan pelatihan mengenai akuntansi perpajakan dan memberikan buku-buku referensi mengenai akuntansi perpajakan. 
ISSN 2657-1080

ISSN 1858-3687

Akuntansi dan Manajemen Vol.14, No.1, 2019

\section{REFERENSI.}

Agoes, Sukrisno. 2013. Akuntansi Perpajakan. Edisi 3. Jakarta. Alemba Empat

Peraturan Pemerintah. 2016. PP No. 16 Tahun 2016.

Resmi, Siti. 2017. Perpajakan : Teori dan Kasus. Buku 2, ed.10. Jakarta : Salemba Empat.

Waloyo. 2017. Perpajakan Indonesia :. Buku 1, ed.12. Jakarta : Salemba Empat

Waloyo. 2017. Perpajakan Indonesia :. Buku 2, ed.12. Jakarta : Salemba Empat 